ciatura (four-year undergraduate degrees). Representing 65 percent of the 777 total demand-absorbing ones, 506 institutions report Ioo percent "hourlies" (part-timers) as the composition of their teaching staff. Seventy-nine percent of the institutions offer only licenciatura, while the remaining 2I percent of institutions offer licenciatura plus some master's degrees. Few of these degrees require a costly infrastructure for laboratories or technology, and most of them are in the fields of administrative sciences, humanities, and education, or computer sciences, with aspirations of a fast immersion into the job market.

\section{African Higher Education: Projecting the Future Damtew Teferra}

Damtew Teferra is Director for Africa and the Middle East at the Ford Foundation International Fellowships Program based in New York. He directs the International Network for Higher Education in Africa. E-mail: teferra@bc.edu.

$T^{n}$ the last decade, higher education in Africa has seen policy 1 shifts in favor of higher education, massive demand and major growth in providers, and unprecedented progress in information and communications technologies. However, the region has also faced large numbers of unemployed and unemployable graduates, uncertainty due to international regimes such as the General Agreement on Trade in Services (GATS), diminishing faculty numbers, and massive brain drain.

\section{EMANCIPATION AND REVITALIZATION}

African higher education survived under the shadow of international sanctions for several decades following the rate-ofreturn study supported by the World Bank in mid-ig8os that defined higher education as a luxury the continent could ill afford. The World Bank dropped loan requests for higher education development on the continent. Other international development partners and major philanthropic organizations, even some considered to be fiercely independent, followed the same policy track, dropping higher education from their development agenda. African governments themselves neglected universities largely due to external influence.

With the publications of Higher Education and Developing Countries: Peril and Promise (World Bank, 2000) and Constructing Knowledge Societies (World Bank, 2002), which affirmed the role of higher education in the globalized world, the World Bank's position has shifted in favor of higher educa- tion, in effect emancipating the system in the region. This approach has created the opportunity for the bank, other development partners, and respective governments to revitalize and expand the higher education system on the continent. One may mark this major policy shift as the most important development in African higher education landscape over the last decade.

\section{Private Expansion: Public Influence}

In many countries, upgraded and brand-new public institutions have experienced hikes in student enrollment. Even more so, the growth of private institutions has been phenomenal. For example, in Ethiopia, where virtually no such institution existed a decade ago, over 60 operate now. There are 18 in Kenya, 20 in Tanzania, and 32 in Nigeria. One of the most remarkable developments in the continent's higher education system is the mushrooming of private colleges. However, the demand for access is still far from fulfilled, with a total 5 percent enrollment in the region.

As the liberalized global economic policies encouraged the growth of private institutions on the continent, the expansion had a direct and indirect impact on the funding of public higher education institutions. In response, the trend provided public institutions an impetus for practicing several cost-sharing initiatives that some observers dub as the "privatization" of public institutions. The taboo regarding revenue generation has eased up, and controversies surrounding cost sharing have

As access to higher education is rapidly expanding in the region, quality has emerged as a growing concern for stakeholders-students, parents, guardians, employers, and governments.

been muted. These developments, however, are being re-evaluated as issues of equity, quality, and access are being raised. Even more so, the private expansion has fostered negligence of public higher education expansion by financially strapped governments, limiting their support to the subsector.

Numerous threads are shared among the recently established nonsectarian private institutions in the region-and around the world. These institutions are generally smaller in size, limited to programs of popular demand, market oriented, and fee and tuition dependent. They often rely on staff from major public institutions, largely part-timers, virtually none of whom pursue research; postgraduate programs are rarely offered.

Private higher education institutions, especially those dependent on tuition and fees are generally unstable, precarious, and resource challenged. Yet, private higher education providers in the region that are established, funded, and run by religious groups are growing in number and significance. 


\section{EXPANDING ACCESS AND QUALITY}

As access to higher education is rapidly expanding in the region, quality has emerged as a growing concern for stakeholders-students, parents, guardians, employers, and governments. The concern acutely affects private institutions, whose credibility on the continent is not yet established given the questions of the public and governments on the sector's fast growth, delivery, and accountability.

Over the last several years, many countries have established

\section{Whereas Africa remains as the least wired (and} wireless) region in the world, the transformation brought about by ICT has considerably contributed to teaching, research, and publishing in the region's institutions.

quality assurance and accreditation offices that have already made some progress in registering and accrediting, as well as revoking licenses of providers. The status and operational standards of these institutions in the region leave a lot to be desired.

In this environment, private providers in some countries are proactively policing themselves, protecting their interests, shaping pertinent dialogue, and collectively raising their grievances. One such example is the Association of Private Institutions in Ethiopia, established in 2005.

\section{Public Funding: A Diminishing Trend?}

Higher education in Africa is still mainly a public affair, though this situation is changing fast. Funding will remain the ongoing issue for the expansion and reinvigoration of the higher education system in Africa. Low economic growth rates, weak investment outlooks, unsustainable unemployment rates, grinding poverty, and rampant disease (e.g., HIV-AIDS) will continue to constrain Africa's ability to generate meaningful revenues in the context of a deregulated education subsystem, which until recently was dubbed "a luxury."

\section{Academic Freedom and Autonomy: Winds of Change?}

Africa has largely been known as a bastion of military and authoritarian dictatorships that represses its population-and its intellectuals. As the wind of democratization blows across the region, chipping away one dictator after another, the human rights and intellectual space of nations are buddingabeit slowly.

As opposition movements and civic organizations on the continent are flourishing, the role of universities as a vanguard of social movements has considerably diminished. Indeed, many of the recent leaders and opposition politicians had been university professors, intellectuals, and other high-level professionals who have themselves fought tyranny and tend to be more tolerant toward academic freedom and autonomy of universities.

\section{ICT: SUCCESSES AND GLITCHES}

Brain drain, the exodus of highly skilled personnel, remains a chronic challenge to higher education and general development. However, the innovations in information and communications technology (ICT) have enabled migrant intellectuals to participate in the academic and scholarly initiatives of their home countries-in terms of teaching, joint research and publishing, and consultancy.

Whereas Africa remains as the least wired (and wireless) region in the world, the transformation brought about by ICT has considerably contributed to teaching, research, and publishing in the region's institutions.

Access to e-mail, the Internet, and e-journals has helped address the isolation the African intelligentsia has long faced. Communication among fellow scholars and researchers has been dramatically boosted, enabling effective links across the region - and the world.

Yet, low bandwidth, the high cost of service, erratic and unreliable power supply, poor technical support, the short life span of software and hardware, and constant demand for their upgrade will continue to challenge ICT experience in the region.

\section{CONCLUSION}

The liberation from the longstanding unfavorable policies of external agencies, the synergy generated by the knowledge economy, the liberalizing regional economy, and the unprecedented ICT developments have had a considerable impact upon higher education development on the continent over the past decade.

Higher education in Africa is still mainly a public affair, though this situation is changing fast.

The outstanding challenges that remain include low enrollment rates (accompanied by inequity) and massive demand, limited funding capability, diminishing faculty (due to age and mortality), poor-quality teaching and low research output, "unfit" graduates, massive brain drain, and uncertainty of international initiatives such GATS.

As higher education takes a central position in the knowledge economy, establishing dynamic institutions has become crucial. To become a meaningful player, Africa thus must make a serious effort to build a strong higher education system. 